\title{
Identification of genes associated with growth cessation and bud dormancy entrance using a dormancy-incapable tree mutant
}

\author{
Sergio Jiménez ${ }^{1 \dagger}$, Zhigang $\mathrm{Li}^{1 \dagger}$, Gregory L Reighard ${ }^{1}$, Douglas G Bielenberg ${ }^{1,2^{*}}$
}

\begin{abstract}
Background: In many tree species the perception of short days (SD) can trigger growth cessation, dormancy entrance, and the establishment of a chilling requirement for bud break. The molecular mechanisms connecting photoperiod perception, growth cessation and dormancy entrance in perennials are not clearly understood. The peach [Prunus persica (L.) Batsch] evergrowing (evg) mutant fails to cease growth and therefore cannot enter dormancy under SD. We used the evg mutant to filter gene expression associated with growth cessation after exposure to SD. Wild-type and evg plants were grown under controlled conditions of long days (16 h/8 h) followed by transfer to SD (8 h/16 h) for eight weeks. Apical tissues were sampled at zero, one, two, four, and eight weeks of SD and suppression subtractive hybridization was performed between genotypes at the same time points.

Results: We identified 23 up-regulated genes in the wild-type with respect to the mutant during SD exposure. We used quantitative real-time PCR to verify the expression of the differentially expressed genes in wild-type tissues following the transition to SD treatment. Three general expression patterns were evident: one group of genes decreased at the time of growth cessation (after 2 weeks in SD), another that increased immediately after the SD exposure and then remained steady, and another that increased throughout SD exposure.

Conclusions: The use of the dormancy-incapable mutant evg has allowed us to reduce the number of genes typically detected by differential display techniques for SD experiments. These genes are candidates for involvement in the signalling pathway leading from photoperiod perception to growth cessation and dormancy entrance and will be the target of future investigations.
\end{abstract}

\section{Background}

Dormancy is defined as the inability to initiate growth from meristems under favourable conditions [1]. The first step towards establishing dormancy is growth cessation. Photoperiod has been known to govern growth cessation and dormancy entrance in many perennial species in temperate climates [2,3], including peach [Prunus persica (L.) Batsch]. Bud formation is concomitant with dormancy entrance, although it is not required and seems to be independent of dormancy establishment [1]. Cold acclimation may also be induced by some of the same environmental factors as bud

\footnotetext{
* Correspondence: dbielen@clemson.edu

+ Contributed equally

'Department of Horticulture, Clemson University, Clemson, SC 29634-0319,
} USA

(C) 2010 Jiménez et al; licensee BioMed Central Ltd. This is an Open Access article distributed under the terms of the Creative Commons Attribution License (http://creativecommons.org/licenses/by/2.0), which permits unrestricted use, distribution, and reproduction in any medium, provided the original work is properly cited. dormancy but does not appear to be mechanistically linked to dormancy induction $[4,5]$.

Several recent studies have used global approaches to analyze the molecular mechanisms of dormancy. Expression profiling during dormancy induction, maintenance and release were analyzed in Populus tremula [6], P. tremula $\times$ P. alba [5,7], P. deltoides Bartr. ex Marsh [4], Norway spruce [8], oak [9], leafy spurge [10-12], raspberry [13], grapevine [14], peach [15], and apricot [16]. These studies have described an initial set of candidate genes involved in cold- or light-induced dormancy in tree species.

The use of transgenic mutants for comparative analysis has been another approach to analyze the molecular mechanism of dormancy. There is evidence that the short day (SD) dormancy-inducing signal is mediated through phytochrome and the FLOWERING TIME 
(FT)/CONSTANS $(C O)$ module $[17,18] . P$. tremula $\times P$. tremuloides trees over-expressing $F T$ do not stop growing upon exposure to SD and bud set could be induced independently from SD by down-regulation of FT [18]. It has also been proposed that a change in carbohydrate metabolism could induce ethylene biosynthesis before the formation of the bud structure [5,19]. Over-expression of ABCISIC ACID-INSENSITIVE3 (ABI3) gene in poplar prevents the formations of closed apical buds upon SD induction, indicating that abscisic acid (ABA) could contribute to the transition to closed bud $[5,20]$. However, only certain downstream components of the signal transduction chain are known and their connections are poorly characterized. The molecular mechanisms responsible for growth arrest are still not clearly understood, because of bud formation, growth cessation and cold acclimation processes overlap in time with seasonal changes in light quality, temperature, and day length. Responses to SD and low temperature conditions independent of growth cessation and dormancy-induction complicate global gene expression analyses, particularly when experiments are performed in the field during natural seasonal transitions [5]. It is therefore difficult to associate molecular changes with specific physiological events.

The peach mutant evergrowing (evg), a non-dormant genotype identified from southern Mexico, fails to cease growth and enter dormancy under dormancy-inducing conditions [21,22]. The evg mutant does not form apical buds in response to short days and/or cold temperatures, and growth of terminal meristems is continuous. The evg trait segregates as a single recessive nuclear gene [22], and corresponds to a deletion in the linkage group one (LG1) of the Prunus reference genetic map $[21,23]$. A cluster of SVP-like (SHORT VEGETATIVE $P H A S E)$ MADS-box genes is located in this deleted region and these genes are not expressed in the peach mutant evg [21,24]. Three of the six SVP-like genes, named dormancy associated MADS-box (DAM) genes, are most likely to be responsible for the continuous growth phenotype of the mutant [25].

The evg mutant has been proposed as a useful system for studying winter seasonal growth behavior [22]. Recent studies have provided information regarding the putative molecular basis of the evg mutation as the loss of six DAM genes $[21,23,26]$. Here we used the evg mutant to investigate the development of growth arrest and endodormancy. We have used wild-type (WT) and the continuous growth, dormancy-incapable evg mutant genotypes to identify genes differentially expressed following transition to a SD photoperiod. Dormancy-incapable evg was used as a filter to reduce SD-induced differential gene expression signals common to both genotypes, and therefore not involved in signalling growth cessation and dormancy entrance. We found genes that can be placed in the photoperiod response pathway disrupted by the evg mutation.

\section{Methods}

\section{Plant materials and growth condition}

Rooted cuttings from a $\mathrm{F}_{2}$ sibling population segregating for WT and evg phenotypes were grown in Fafard 3B soilless mix (45\% peat moss, $15 \%$ perlite, $15 \%$ vermiculite, 25\% bark; Fafard, Agawam, MA, USA) and sand $(2: 1 \mathrm{v} / \mathrm{v}), 3.5 \mathrm{~g} \mathrm{~L}^{-1}$ Osmocote 14-14-14 (Scotts, Marysville, $\mathrm{OH}, \mathrm{USA}$ ) and $3.5 \mathrm{~g} \mathrm{~L}^{-1}$ dolomitic lime (Oldcastle, Atlanta, GA, USA), for 2 months in a greenhouse at $25^{\circ}$ $\mathrm{C}$ with $16 \mathrm{~h}$ light/8 h dark. WT and evg plants were transferred to a growth room for two weeks of acclimation under long days (LD, $16 \mathrm{~h}$ light/8 h dark) and shifted to SD (8 h light/16 h dark) photoperiod conditions for eight weeks. In both photoperiod treatments, all other environmental conditions were identical: 250$300 \mu \mathrm{mol}$ photon $\mathrm{m}^{-2} \mathrm{~s}^{-1}$ light intensity at canopy height was provided by AgroSun ${ }^{\circledR}$ Gold $1000 \mathrm{~W}$ sodium/halide lamps (Agrosun Inc, New York, NY, USA), temperature was $22.5^{\circ} \mathrm{C}$ during light and $18.7^{\circ} \mathrm{C}$ during dark and relative humidity was $48 \%$ during light and $55 \%$ during dark. Plants were watered every two days as needed.

Primary axis elongation was measured weekly on 29 WT and 15 evg plants. Re-growth potential in permissive conditions (LD) was assessed weekly following the transition to short days: replicate WT trees were transferred from SD to LD conditions and vegetative bud break and resumption of growth was observed during following two weeks.

Apical tissues were sampled from WT and evg trees at $0,1,2,4$, and 8 weeks following transfer to SD. Sixteen (WT) or eight (evg) apical tips were pooled from each genotype at each time for suppression subtractive hybridization (SSH). Three WT and three evg apical tips were harvested at each time for gene expression analysis by real-time PCR.

\section{RNA isolation and reverse transcription}

After sampling, plant tissues were immediately frozen in liquid nitrogen and stored at $-80^{\circ} \mathrm{C}$. Total RNA was isolated using the protocol of Meisel et al [27]. After DNase I treatment (Invitrogen, Carlsbad, CA, USA) to eliminate possible genomic DNA contamination, $2.5 \mu \mathrm{g}$ of total RNA were reverse transcribed using an oligo $(\mathrm{dT})_{20}$ as a primer with SuperScript III first strand synthesis system for reverse transcriptase (RT)-PCR (Invitrogen).

\section{Suppression subtractive hybridization}

Suppression subtractive hybridization (SSH) PCR between WT and evg samples, within each sampling 
date, was performed using the Clontech PCR-Select cDNA Subtraction Kit (Clontech Laboratories, Palo Alto, CA, USA), starting with $2 \mu \mathrm{g}$ of sample polyA ${ }^{+}$ RNA purified from total RNA using Dynabeads Oligo $(\mathrm{dT})_{25}$ (Invitrogen). Forward-subtracted, reverse-subtracted, and unsubtracted hybridizations were performed following the manufacturer's instructions for the identification of clones enriched in one genotype relative to the other. The subtracted cDNA population of each hybridization was purified with QIAquick PCR purification kit (Qiagen, Inc., Valencia, CA, USA) and cloned in pGEM-T Easy using pGEM-T Easy cloning kit (Promega, Madison, WI, USA).

A total of 11,520 clones from subtracted cDNA libraries $(1,152$ per each forward and reverse subtracted library per sampling date) were screened for up-regulated or down-regulated expression in the WT or evg by hybridization. Clones were grown in plates, transferred to Hybond $-\mathrm{N}^{+}$filters (Amersham Biosciences, GE Healthcare Ltd, Little Chalfont Buckinghamshire, UK), lysed and DNA was fixed by oven baking. Each subtracted library was hybridized with forward- and reverse-subtracted and unsubtracted radiolabeled cDNA probes with adaptors removed to avoid the loss of lowabundance differentially expressed mRNAs. A total of 177 clones were selected as having strong hybridization signals in the selected were successfully sequenced and subjected to a BLASTx against GenBank database. Sequences without similarity were analyzed again using tBLASTx or BLASTn. Sequences were evaluated for redundancy, and differential expression between WT and evg was confirmed by real-time PCR.

\section{Expression analysis by real-time PCR}

Real-time PCR was performed on an iCycler iQ system (Bio-Rad, Hercules, CA, USA) using the iQ SYBR-Green Supermix (Bio-Rad, Hercules, CA, USA). Gene-specific primers for each of the selected genes were used (Table 1) to amplify products from synthesized cDNA samples with the SuperScript III first strand synthesis system for reverse transcription (RT)-PCR (Invitrogen). Three technical replications for each of the three biological replicates were performed. PCR was conducted with the following program: an initial DNA polymerase activation at $95^{\circ} \mathrm{C}$ for $180 \mathrm{~s}$, then followed by 40 cycles of $95^{\circ} \mathrm{C}$ for $30 \mathrm{~s}, 60^{\circ} \mathrm{C}$ for $30 \mathrm{~s}$, and $72^{\circ} \mathrm{C}$ for $30 \mathrm{~s}$. Finally, a melting curve was performed, and the PCR products were checked with $2 \%$ agarose gel in $1 \times$ TAE with ethidium bromide.

Fluorescence values were baseline-corrected and averaged efficiencies for each gene and $\mathrm{Ct}$ values were calculated using LinRegPCR program [28]. Gene expression measurements were determined with the Gene Expression Ct Difference (GED) formula [29]. The gene expression levels were normalized to a peach EST
(GenBank Accession Number DY652828), similar to the Arabidopsis thaliana expressed gene At5g12240 [30], and were expressed relative to the values at week 0 (LD). The reference gene At5g12240 showed a low variability of expression within biological replicates and a stable expression throughout the experiment a with a stability index of 0.12 for WT and 0.25 for evg (calculated as in [31]). The reference gene At5g12240 showed better stability index values than $\alpha$-tubulin (from EST Tua5, GenBank Accession DY650410).

\section{Statistical analysis}

Statistical testing of quantitative expression level between WT and evg within sampling date was performed with the Mann-Whitney-Wilcoxon test $(P<$ $0.05)$. Growth elongation was analyzed with the twosample paired t-test $(P<0.05)$ at each sampling date. Analyses were performed using the statistical software version package of SAS v.9.1.3 (SAS Institute Inc., Cary, $\mathrm{NC})$.

\section{Results}

\section{Short days rapidly induce growth cessation in WT plants}

WT plants showed apical growth cessation after two weeks of SD (Figure 1). Plants were unable to resume growth in LDs after three weeks of SD exposure (Figure 1). Evg plants did not show slowed growth until several weeks of SD exposure (Figure 1), but were able to immediately resume growth when transferred to LDs even after eight weeks of SD treatment. The slowed growth observed in the evg plants at the end of the experiment was likely caused by the decreased total integrated light exposure resulting from reducing the light period from 16 to 8 hours without altering the light intensity.

\section{Differentially expressed genes and functional classification}

cDNAs prepared from WT and $e v g$ apical tissue were used as testers and drivers for SSH PCR. A total of 11,520 clones from subtracted cDNA libraries were screened for up-regulated or down-regulated expression in the WT or evg by hybridization. After comparing the signal among forward- and reverse-subtracted and unsubtracted radiolabeled cDNA probes, we selected 177 clones for sequencing. These 177 sequences assembled into 106 contigs. The majority of the 106 sequences were up-regulated in WT relative to evg. Following the selection of the highest signal spots and verification by real-time PCR, we identified 23 genes as upregulated in the WT relative to evg in response to $\mathrm{SD}$ conditions.

Differentially expressed genes were assigned to five categories according to their putative functions 
Table 1 Gene bank accession numbers and primer sequences used in real-time PCR of differentially expressed ESTs

\begin{tabular}{|c|c|c|c|}
\hline Gene name & EST bank accession \# & & Forward $(F)$ and reverse $(R)$ primer sequence \\
\hline \multirow[t]{2}{*}{ Desiccation-related protein, putative } & GE653173 & $\mathrm{F}$ & 5'-AGGGCTCGACGATATCAGTCC-3' \\
\hline & & $\mathrm{R}$ & 5'-TGCATACGGGTCAAATGCAGG-3' \\
\hline \multirow[t]{2}{*}{ Amidase family protein } & GE653170 & $\mathrm{F}$ & 5'-CGGTTCGATCCTTGGCAGAC-3' \\
\hline & & $\mathrm{R}$ & 5'-TCGACACGGCTGCAAATGGAG-3' \\
\hline \multirow[t]{2}{*}{ Deoxynucleoside kinase family protein } & GE653171 & $\mathrm{F}$ & 5'-AGGAGGACAGCTCGAACTCAG-3' \\
\hline & & $\mathrm{R}$ & 5'-GCATACCTCTGCGGCTCAGC-3' \\
\hline \multirow[t]{2}{*}{ Auxin-binding protein $\mathrm{ABP} 20$ precursor } & GE653207 & $\mathrm{F}$ & 5'-AGCCTCACCTCCATTGACTTGG-3' \\
\hline & & $\mathrm{R}$ & 5'-TGTTGCTCAGTTTCCTGGTGTGA-3' \\
\hline \multirow[t]{2}{*}{ Amino acid transporter family protein } & GE653321 & F & 5'-GGCTTCACCCATGACATCACC-3' \\
\hline & & $\mathrm{R}$ & 5'-CTGGAATTATGAGCCTGCCTGC-3' \\
\hline \multirow[t]{2}{*}{ Glycoside hydrolase, family 18} & GE653328 & $\mathrm{F}$ & 5'-CAGTCCACCACTCCCATCACTG-3' \\
\hline & & R & 5'-GCTTCCATTGCTCCCTTCGATG-3' \\
\hline \multirow[t]{2}{*}{ ATP sulfurylase 1} & GE653245 & $\mathrm{F}$ & 5'-ACAAGACGCAATGCTGATGCTG-3' \\
\hline & & $\mathrm{R}$ & 5'-ACCACAGTCGTCTCAGGATCAAG-3' \\
\hline \multirow[t]{2}{*}{ KEG (KEEP ON GOING) protein } & GE653332 & $\mathrm{F}$ & 5'-ACCCGTTCTATTTCCGATGCCT-3' \\
\hline & & $\mathrm{R}$ & 5'-TCAGTTTCAACTCCAACCCACCA-3' \\
\hline \multirow[t]{2}{*}{ Phosphatidylinositol 3- and 4-kinase family protein } & GE653311 & $\mathrm{F}$ & 5'-GGGTTGGGGAGACAGGTTTCA-3' \\
\hline & & $\mathrm{R}$ & 5'-AGTCCCATGATCACTGGCATCA-3' \\
\hline \multirow[t]{2}{*}{ PRH75 (DEAD-box helicase) } & GE653257 & F & 5'-TGTAGCCAGCAGCCTTAGCAAG-3' \\
\hline & & $\mathrm{R}$ & 5'-GCCAGTTGATGTTGCCAAAGCAG-3' \\
\hline \multirow[t]{2}{*}{ Zinc ion binding/LIM } & GE653319 & $\mathrm{F}$ & 5'-AGAAGAGGATGAGGAGGAAGACG-3' \\
\hline & & $\mathrm{R}$ & 5'-GTTGTTGACAGGGTCGATTCTGG-3' \\
\hline \multirow[t]{2}{*}{ ATP-binding cassette transporter MRP6 } & GE653330 & $\mathrm{F}$ & 5'-CTGGGATTGTGGGTAGAACTGG-3' \\
\hline & & $\mathrm{R}$ & 5'-CCTTCAAACATGGTTGGGTCCTG-3' \\
\hline \multirow[t]{2}{*}{ Unknown1 } & GE653303 & $\mathrm{F}$ & 5'-СTCTCTGTGCTTCTCTCTCCTCA-3' \\
\hline & & $\mathrm{R}$ & 5'-TCCAGATTAACTCAGGGAGAAACCAG-3' \\
\hline \multirow[t]{2}{*}{ Late embryogenesis abundant (LEA) } & GE653244 & $\mathrm{F}$ & 5'-TTCAAATTCTCCGGGGGTCG-3' \\
\hline & & $\mathrm{R}$ & 5'-TTCCAGGCCATCTTCCACGG-3' \\
\hline \multirow[t]{2}{*}{ Metallothionein-like protein } & GE653329 & $\mathrm{F}$ & $5^{\prime}$-TCCACCAATCAACAAACACCTCAC-3' \\
\hline & & $\mathrm{R}$ & 5'-TAGCAAGTAATCTATGCGTGTGTGG-3' \\
\hline \multirow[t]{2}{*}{ Pathogenesis-related protein 1a (PR-1a) } & GE653248 & $\mathrm{F}$ & 5'-CGACTGCAATCTTGTCCACTCTGG-3' \\
\hline & & $\mathrm{R}$ & 5'-ACCTCCACTGTTGCACCTCAC-3' \\
\hline \multirow[t]{2}{*}{ Dormancy associated MADS-box gene 1 (PpDAM1) } & GE653327 & $\mathrm{F}$ & $5^{\prime}-$ CAGAGGGCAAGCAACTACCAC-3' \\
\hline & & $\mathrm{R}$ & 5'-CCAGAGAAATTATGGAAGCCCCA-3' \\
\hline \multirow[t]{2}{*}{ Dormancy associated MADS-box gene 6 (PpDAM6) } & GE653238 & $\mathrm{F}$ & 5'-CCAACAACCAGTTAAGGCAGAAGA-3' \\
\hline & & $\mathrm{R}$ & 5'-GGAAGCCCCAGTTTGAGAGA-3' \\
\hline \multirow[t]{2}{*}{ Epicotyl-specific tissue protein } & GE653203 & $\mathrm{F}$ & 5'-CACCAAAAGAGAAAGCCGACTGC-3' \\
\hline & & $\mathrm{R}$ & 5'-TCAACCTCAACGTCAACCTCAAC-3' \\
\hline \multirow[t]{2}{*}{ RD22 (dehydration-responsive) precursor } & GE653312 & $\mathrm{F}$ & 5'-GAACCCACACAAGATTATCAGCAGG-3' \\
\hline & & $\mathrm{R}$ & $5^{\prime}-T T C T A C T G C C A C A G C C A G C A-3^{\prime}$ \\
\hline \multirow[t]{2}{*}{ Unknown2 } & GE653334 & F & 5'-ATGGCAAACCACCAAGCACTCA-3' \\
\hline & & $\mathrm{R}$ & 5'-GTAGAGGAGCCTTGATTGGAGGAG-3' \\
\hline \multirow[t]{2}{*}{ Unknown3 } & GE653309 & $\mathrm{F}$ & 5'-AAGTTGTCCATCCCAACACATTCG-3' \\
\hline & & $\mathrm{R}$ & 5'-GCGAGGACATCTCTGGCAATAAGA-3' \\
\hline \multirow[t]{2}{*}{ Unknown4 } & GE653307 & $\mathrm{F}$ & 5'-TCCTCAACGAACAGACGGAACTC-3' \\
\hline & & $\mathrm{R}$ & 5'-TGGTGGTCTTGGAAATGCTGGT-3' \\
\hline
\end{tabular}




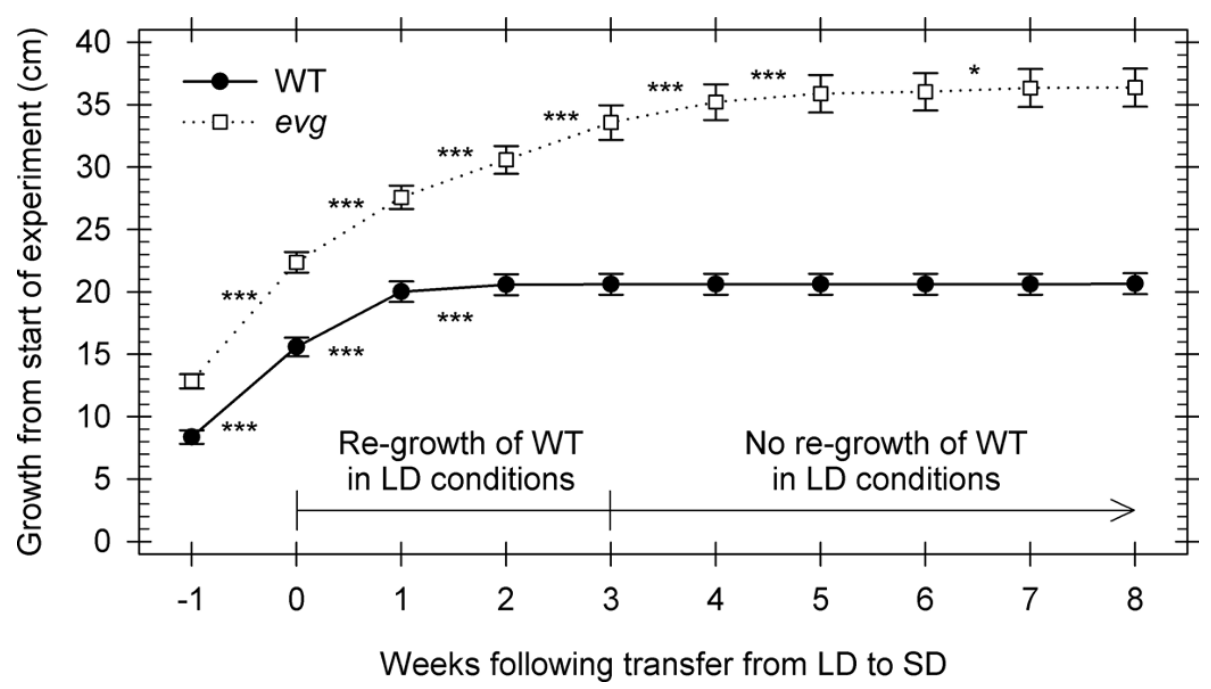

Figure 1 Stem growth and potential re-growth of WT and evg plants after transferring to SD. Stem growth (increase in length) was measured one week prior and eight weeks after transfer of WT and evg plants from LD (16 h light) to SD (8 h light) photoperiod conditions and potential re-growth when WT plants are transferred back to LD conditions. The day of treatment change to SD conditions is named week 0. Data are mean \pm SE of 29 and 15 replicates for WT and evg, respectively. Growth elongation significance between paired dates is indicated: not significant, not showed; * $P<0.05, * * *, P<0.001$.

generated by similarity searches against the GenBank database. Although the number of genes obtained was very limited, the largest group of genes $(30 \%)$ was signaling/transcription related genes followed by genes with unknown (26\%) and defense functions (22\%). One of the unclassified proteins (unknown3) had no sequence similarity in GenBank.

Seventeen of the 23 genes showed statistically significant increased expression with real-time PCR in the WT relative to evg (Figure 2) by ANOVA with the Mann-Whitney test. The expression of two DAM genes, PpDAM1 and PpDAM6, was observed in WT tissue and as expected we did not detect expression of these genes in evg tissue by real-time PCR.

\section{Gene expression in SD conditions}

We measured the expression response of the 23 genes identified above to the LD to SD transition in WT tissues by real-time PCR. Gene expression in the WT following the LD to SD transition showed three distinct patterns (Figure 2). The first group of genes had a stable or increased expression immediately following transition to SD peaking at two weeks. The expression peak of these genes coincides with growth cessation in the WT. After two weeks in SD, expression of these genes then decreased to values similar or below those in LD conditions (Figure 2). Defence, metabolism, signalling/transcription and transport genes were included in this group. The putative amidase showed stable expression in both WT and evg plants in the first and second weeks after transfer to $\mathrm{SD}$, followed by down-regulation in both genotypes, although its expression decreased faster in the WT compared with evg (Figure 3A). The auxin-binding protein 20 (ABP20) transcript showed a transient up-regulation after the second week of SD followed by down-regulation in WT apical tissue, whereas the expression remained stable in evg (Figure 3B).

The second group of genes had an increased expression in WT tissue immediately following transition to SD that was maintained steady until the end of the experiment or similar to the LD values (Figure 2). The putative glycoside hydrolase 18 (GH18), ATP sulfurylase 1, KEG (KEEP ON GOING), zinc ion binding/LIM, ATP-binding cassette transporter MRP6 and unknown1 followed this profile in WT (Figure 4A-F). However, in general the expression of these genes remained stable in evg.

The third group of genes had a delayed response in WT tissue. In general, their expression increased after one to two weeks of SD exposure and continued to increase until the end of the experiment (Figure 2). Defence, unknown, and signalling/transcription genes were included in this second group. The putative late embryogenesis abundant (LEA) protein, metallothionein, pathogenesis-related protein 1a (PR-1a), PpDAM1, PpDAM6, epicotyl-specific tissue protein, unknown2, unknown3 and unknown4 genes followed this profile in WT (Figure 5A-I). However, in general the expression of these genes remained stable in evg. Two of these genes, the putative LEA and epicotyl-specific tissue protein genes, showed a large up-regulation the last week of the experiment. The expression of putative LEA and 


\begin{tabular}{|c|c|c|c|c|c|c|c|c|c|}
\hline \multirow[b]{2}{*}{ Best hit against NCBI non redundant database } & \multirow[b]{2}{*}{$\begin{array}{l}\text { BLAST } \\
\text { E-value }\end{array}$} & \multirow[b]{2}{*}{$\begin{array}{l}\text { Best hit } \\
\text { accession } \\
\text { number }\end{array}$} & \multirow[b]{2}{*}{ Putative function } & \multirow{2}{*}{$\begin{array}{c}\text { Relative } \\
\text { Expression } \\
\text { WT vs. evg } \\
\text { (fold) at time } \\
\text { of SSH }\end{array}$} & \multirow{2}{*}{$\begin{array}{c}\text { Statistically } \\
\text { significant } \\
\text { expression } \\
\text { difference } \\
\text { WT vs. evg }\end{array}$} & \multicolumn{4}{|c|}{$\begin{array}{l}\text { Relative Expression in } \\
\text { SD WT tissue vs LD }\end{array}$} \\
\hline & & & & & & $\begin{array}{l}\text { SD1 } \\
\text { vs. } \\
\text { LD }\end{array}$ & $\begin{array}{l}\text { SD2 } \\
\text { vs. } \\
\text { LD }\end{array}$ & $\begin{array}{l}\text { SD4 } \\
\text { vs. } \\
\text { LD }\end{array}$ & $\begin{array}{l}\text { SD8 } \\
\text { vs. } \\
\text { LD }\end{array}$ \\
\hline \multicolumn{10}{|l|}{ Early response } \\
\hline Dessication-related protein, putative & $2.0 \mathrm{E}-60$ & AAM65140 & Defense & 1.8 & No & & & & \\
\hline Amidase family protein & $2.0 \mathrm{E}-43$ & NP_195214 & Metabolism & 11.7 & Yes & & & & \\
\hline Deoxynucleoside kinase family protein & $1.0 \mathrm{E}-108$ & NP_565032 & Metabolism & 1.2 & No & & & & \\
\hline Auxin-binding protein $\mathrm{ABP} 20$ precursor & $1.0 \mathrm{E}-107$ & 004011 & Signal transduction & 1.8 & Yes & & & & \\
\hline Amino acid transporter family protein & $3.0 \mathrm{E}-38$ & NP_198698 & Transport & 1.3 & No & & & & \\
\hline \multicolumn{10}{|l|}{ Steady response } \\
\hline Glycoside hydrolase, family 18 & $4.0 \mathrm{E}-65$ & ABD32310 & Defense & 2.3 & Yes & & & & \\
\hline ATP sulfurylase 1 & $6.0 \mathrm{E}-134$ & NP_188929 & Metabolism & 1.3 & Yes & & & & \\
\hline KEG (KEEP ON GOING) protein & $2.0 \mathrm{E}-93$ & NP_196857 & Signal transduction & 1.9 & Yes & & & & \\
\hline Phosphatidylinositol 3- and 4-kinase family protein & $3.0 \mathrm{E}-49$ & NP_973413 & Signal transduction & 1.9 & No & & & & \\
\hline PRH75 (DEAD-box helicase) & $7.0 \mathrm{E}-117$ & NP_201025 & Transcription & 1.3 & No & & & & \\
\hline Zinc ion binding/LIM & $5.0 \mathrm{E}-85$ & NP_974697 & Transcription & 2.4 & Yes & & & & \\
\hline ATP-binding cassette transporter MRP6 & $1.0 \mathrm{E}-27$ & AAL14776 & Transport & 1.3 & Yes & & & & \\
\hline Unknown1 (Shoot EST PP_LEc0019E03f) & $0.0 \mathrm{E}+00$ & DW344412 & Unknown & 1.9 & Yes & & & & \\
\hline \multicolumn{10}{|l|}{ Late response } \\
\hline Late embryogenesis abundant (LEA) & $8.0 \mathrm{E}-09$ & NP_193834 & Defense & 17.5 & Yes & & & & \\
\hline Metallothionein-like protein & 4.0E-157 & AJ243532 & Defense & 2.3 & Yes & & & & \\
\hline Pathogenesis-related protein 1a (PR-1a) & $3.0 \mathrm{E}-60$ & ABC47922 & Defense & 13.7 & Yes & & & & \\
\hline Dormancy associated MADS-box gene 1 (PpDAM1) & $7.0 \mathrm{E}-24$ & ABJ96361 & Transcription & N/A & Yes & & & & \\
\hline Dormancy associated MADS-box gene 6 (PpDAM6) & $2.0 \mathrm{E}-73$ & ABJ96360 & Transcription & N/A & Yes & & & & \\
\hline Epicotyl-specific tissue protein & $1.0 \mathrm{E}-29$ & ABD98040 & Unknown & 26.9 & Yes & & & & \\
\hline RD22 (dehydration-responsive) precursor & $4.0 \mathrm{E}-74$ & EEF43287 & Unknown & 1.1 & No & & & & \\
\hline Unknown2 (EST122 SSH library clone CF7A-02) & $0.0 \mathrm{E}+00$ & FE969296 & Unknown & 3.9 & Yes & & & & \\
\hline Unknown3 (No hits) & - & - & Unknown & 2.3 & Yes & & & & \\
\hline Unknown4 (Hypothetical protein) & $2.0 \mathrm{E}-12$ & CAN68266 & Unknown & 2.4 & Yes & & & & \\
\hline
\end{tabular}

Figure 2 Putative differentially expressed genes between WT and evg and their expression pattern during SD in WT. Sequences were analyzed using BLASTx tool and using tBLASTx or BLASTn when no similarity was found. Statistical testing of expression level between WT and evg was performed with the Mann-Whitney-Wilcoxon test $(P<0.05)$. Gene expression pattern in WT tissue was calculated as the expression values in SD relative to the values at LD conditions. The color scale is in $\log _{10}$ ratio where a green color corresponds with up-regulated gene in $\mathrm{SD}$, the magenta color with down-regulated color in SD and black color with no change in the expression level.

epicotyl-specific tissue protein genes in WT was 118and 134-fold up-regulated, respectively, eight weeks after transferring to SD relative to LD, whereas their expression in evg was only up-regulated 6- and 24- fold, respectively (Figure 5A, F).

\section{Discussion}

Understanding of the regulatory network involved in vegetative growth cessation and dormancy induction is still limited $[1,2,32]$. We used SSH PCR to identify differentially expressed genes in apical tissue between WT peach and the dormancy-incapable evg mutant.

We found 17 significantly up-regulated genes in the WT with respect to the mutant. Interestingly, more than $25 \%$ of the genes could not have a putative function assigned. A similar proportion of unclassifiable genes were reported in previous studies of dormancy in woody species indicating that representation of seasonally expressed genes in existing databases is low [14].

When considering the WT expression changes following transfer from LD to SD, three patterns could be defined. A first group of genes showed expression only during two weeks after transfer to SD. A second group of genes showed increased expression since the first week after transfer to SD and that was maintained steady or then was similar to values before the transfer. The third group of genes showed progressively enhanced expression throughout all weeks, and 

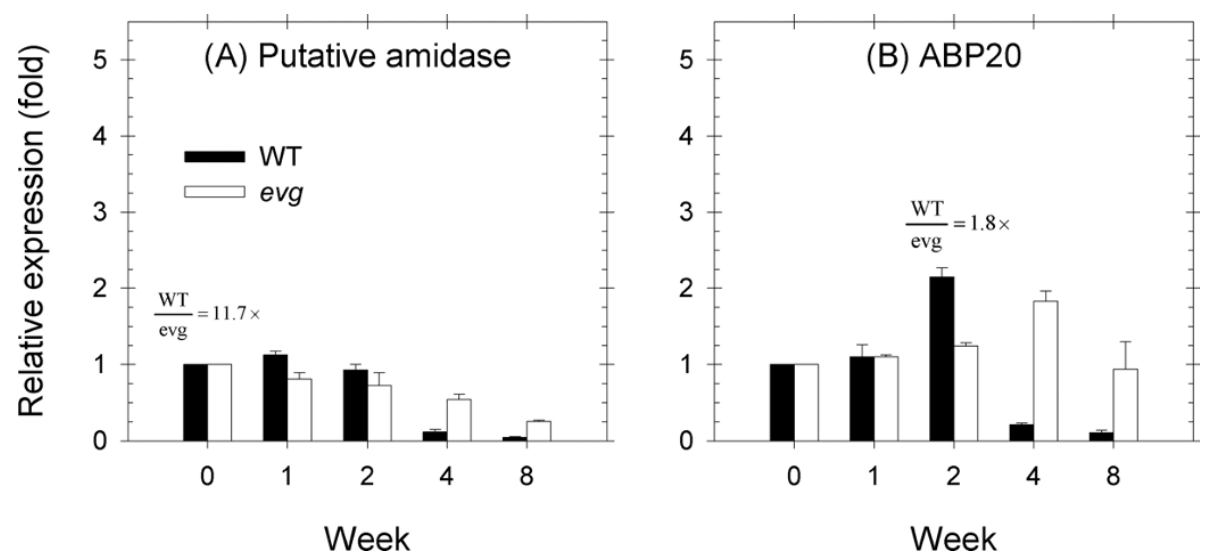

Figure 3 Expression profiles of early response genes in WT and evg apical tissue. Putative amidase (A) and auxin-binding protein ABP20 precursor (B) gene expression is shown relative to the LD level (week 0 prior to the change in photoperiod) for each genotype. Values above columns represent the relative expression (fold) between WT and evg apical tissues at the week where it was maximum.

especially following growth cessation (weeks 4 to 8 ). Two major phases of gene expression response to SD were found previously in poplar: an early response to SD during the first two weeks and then a late adaptation [5]. In another study in poplar, gene expression changed after about three weeks of SD, when bud scales were visible, and after this point there was a large reduction in the number of expressed genes and their expression level [7].

An interesting case of early response is the ABP20 gene whose expression peaked coincident with growth cessation and decreased 10-fold after terminal meristems were unable to resume growth (weeks 4 and 8 ). The peach ABP20 is related to germin and germin-like genes, which belong to the ancient superfamily of cupin proteins. The ABP20 contains a region which shared $40 \%$ of amino acid identity with a putative auxin binding site in ABP1, an auxin-binding protein isolated from maize coleoptiles [33]. This region of homology corresponds with a BoxA domain, whose structure has been suggested to be conserved among proteins that have auxin binding-activity [33,34]. The localization of ABP20 in the cell wall and its ability to produce $\mathrm{H}_{2} \mathrm{O}_{2}$ suggest a similar biological function to germin, which is related
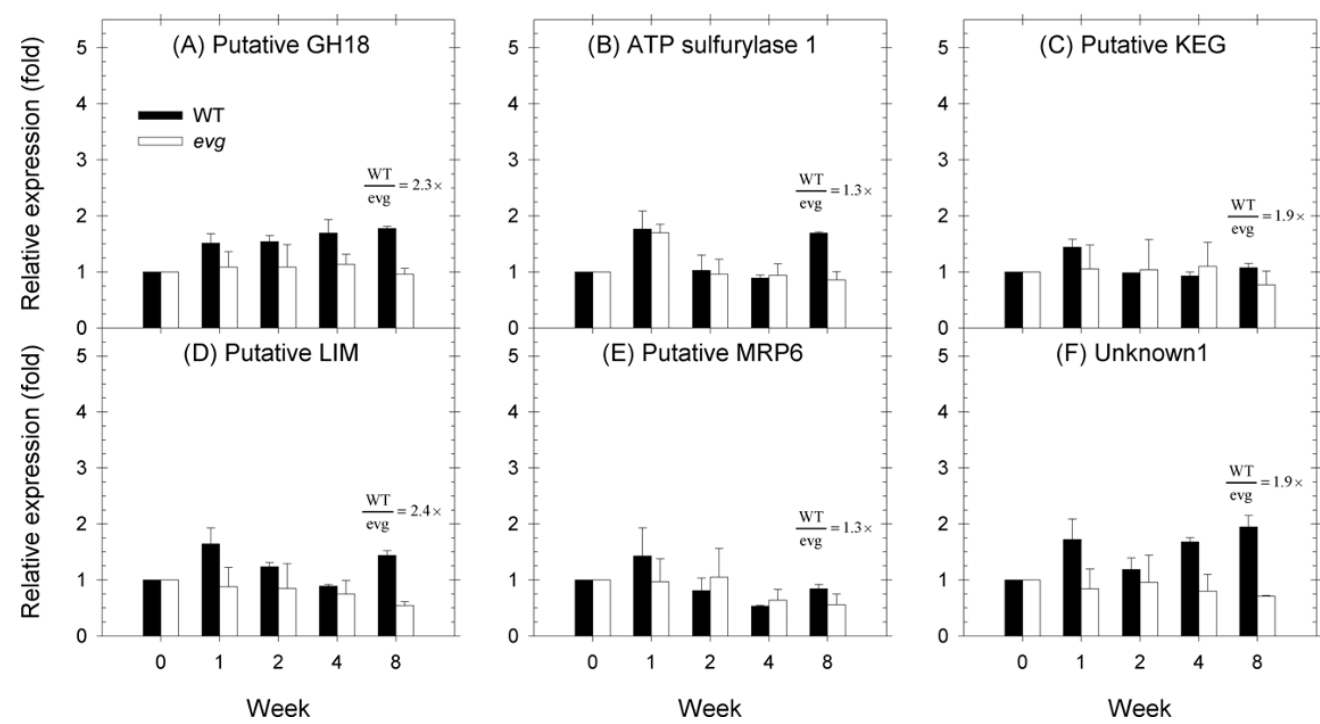

Figure 4 Expression profiles of steady response genes in WT and evg apical tissue. Putative GH18 (A), putative ATP sulfurylase 1 (B), putative KEG (C), putative LIM (D), putativeMRP6 (E) and unknown1 (F) gene expression is shown relative to the LD level (week 0 prior to the change in photoperiod) for each genotype. Values above columns represent the relative expression (fold) between WT and evg apical tissues at the week where it was maximum. 


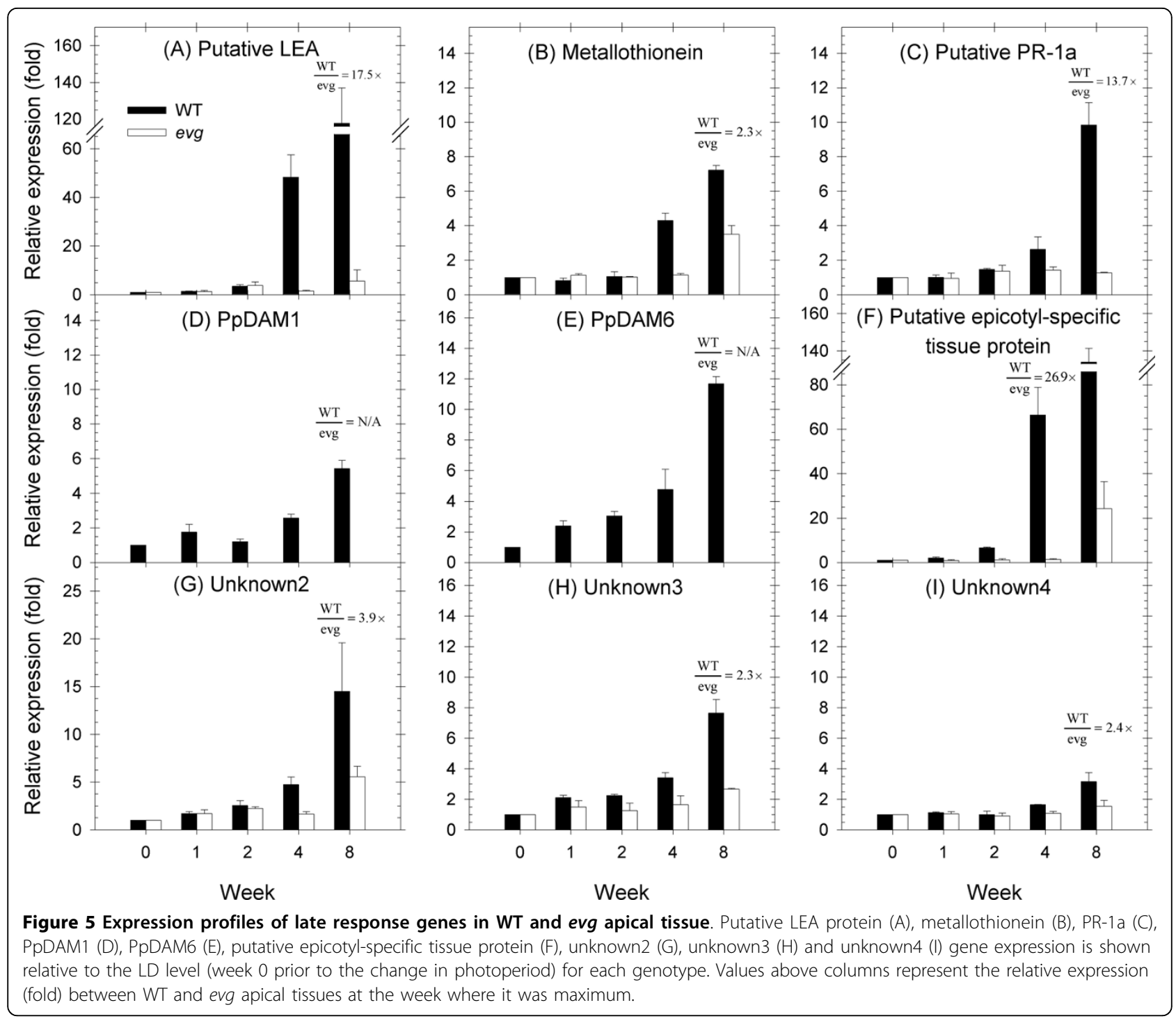

with expansion and lignification of the cell wall [35]. The ABP1 protein of Arabidopsis has been also associated with the auxin-induced cell elongation [36] and has been found to be essential for the auxin control of the cell cycle using tobacco cell culture [37]. Recent studies support the hypothesis of an auxin extracellular receptor role for $\mathrm{ABP} 1[38,39]$. ABP20 gene expression throughout the development of peach vegetative buds was previously reported [35]. In a recent proteomic analysis, the ABP20 protein content in peach bark tissue decreased in after 5 weeks of SD treatment [40]. Several genes involved in auxin metabolism and transport were found down-regulated in the same tissue type and conditions [15]. It has been observed that auxin levels do not change in cambial cells during the dormancy period, but the responsiveness to auxin does [1,41]. Although not definitive, it is tempting to speculate that there may be a role for ABP20 protein in the process of growth cessation in bud tissue by modulating the perception of auxin. However, this hypothesis will have to be specifically tested.

Another early responding gene is the putative amidase. Differential expression of the amidase gene could correspond with the different rate of growth between WT and $e v g$ genotypes, due to the core metabolic function of amidase proteins, however, a specific signalling role cannot be dismissed.

The putative LIM and KEG genes are two cases of steady response with up-regulation during the first week after transfer to SD with this elevated expression maintained similar after that point. Functional analysis is lacking for the peach putative LIM. The LIM protein gene family participates in processes such as gene transcription, cellular organization and signalling [42]. Their 
essential roles have been well characterized in animals; however, only a few members have been studied in plants [42]. A better characterized protein is KEG, a protein capable of mediating ubiquitylation. In Arabidopsis, KEG has an essential role in ABA signalling. During post-germination development, KEG protein is found in Arabidopsis seedlings [43]. The model proposed for KEG function is the ubiquitylation and subsequent degradation of ABI5 (ABSCISIC ACIDINSENSITIVE5) and ABI3 by KEG in the absence of ABA, thus decreasing their ability to suppress growth. In the presence of $\mathrm{ABA}$, this degradation is slowed to allow the transduction cascades resulting in a suppression of growth [43]. There are commonalities between bud and seed dormancy, and although the inducing mechanism might not be shared directly, similar signalling circuits could be adopted [1].

Other steady responding genes are the putative GH18 family gene and unknown 1 . The GH18 subfamily includes chitinases with diverse defence-related functions. Some of them do not have chitinase activity [44], although the putative glycoside hydrolase found in this work exhibited a conserved motif that dictates enzymatic activity. Its expression was found to be up-regulated in WT. GH18 transcripts were found preferentially in active rather than dormant poplar buds [45]. Several chitinases associated with defence-related functions have been found to be up-regulated in Populus dormant cambium tissue and peach bark tissue during dormancy induction $[6,15]$. The unknown1 sequence showed similarity to shoot and fruit peach ESTs, but this is the first report of the regulation of this gene.

During the late response, there is a large up-regulation of the defence-related genes LEA, metallothionein and PR-1. LEA proteins have the presumed role of cellular stabilizers under stress conditions. An Arabidopsis LEA domain-containing gene (At4g21020) similar to the peach gene reported here was found expressed in seeds of Arabidopsis [46]. The increase in LEA expression can be related to the cold acclimation induced by photoperiod, as a protective measure against dehydration. This adaptation to dehydration was also previously found starting in the first weeks of SD-dormancy induced in poplar $[5,7]$. In contrast, a previous study found that SD induced a down-regulation of a different LEA protein in peach bark [15]. LEA genes have been found down-regulated during the dormancy release in raspberry [13] and oak buds [9]. If the LEA gene we have identified is indeed involved in dehydration resistance or cold hardiness, the lagging LEA expression we observed in the evg mutant is consistent with the impaired cold hardiness response previously observed in seasonal LEA expression in evg and deciduous genotypes of peach [47].
Putative metallothioneins were found up-regulated during dormancy release in raspberry [13] and Norway spruce [8], whereas other metallothioneins were found up-regulated during dormancy development in poplar buds [4], in dormant cambial tissue in aspen [6] and during chilling accumulation in grape [14]. Similar metallothioneins to the peach sequence found in our experiment were also expressed during fruit development in apricot and in response to cold stress in apple fruit [48]. Several roles have been defined for metallothioneins: detoxification of heavy metals, homeostasis of essential metal ions, and regulation of gene expression in development processes.

The class 1 pathogenesis-related proteins are not only involved in plant defence responses, but also in development [49]. However, little is known about the molecular function of class 1 pathogenesis-related proteins in plant signalling networks during development. A dual function for some pathogenesis-related proteins as antifreeze proteins during dormancy has been proposed [40]. An increase in PR-1 expression was similarly found during dormancy entrance in poplar [4].

The non-dormant phenotype of the peach evg corresponds to a deletion in the LG1 group of the general genetic map [21,23]. A cluster of DAM genes that belong to the $S V P$-subfamily of MADS-box genes are located in this deleted region [24]. Three of these genes, PpDAM1, PpDAM2 and PpDAM4 are the most likely candidates for the regulation of growth cessation and terminal bud formation [25]. In this work, two of the DAM genes, the PpDAM1 and PpDAM6, were detected and differentially expressed between WT and evg. Their expression was up-regulated after the change in photoperiod and increased continually during bud development. A SVP-like MADS-box factor similar to the PpDAM6 gene showed endodormancy-associated expression in lateral buds of Japanese apricot [16]. Additionally, two putative SVP-like genes, with sequences similar to the PpDAM6 and PpDAM1 genes, were down-regulated during the dormancy release in Rubus idaeus L. buds [13]. The PpDAM6 gene is induced by short photoperiods [25] and unpublished data from our lab shows it to be cold-suppressed. There are six peach DAM genes expressed in WT trees and all six are not expressed in the mutant evg [25]. Here only two of the six genes we know should be definitely differentially expressed between the WT and mutant were detected with the SSH PCR technique we used in this study. This is in line with the known limited sensitivity of SSH for isolating genes like transcription factors that are expressed at low absolute levels.

The most strongly up-regulated gene after several weeks of SD photoperiod inducing-conditions was similar to the epicotyl-specific tissue protein from Striga 
asiatica. A similar protein in Cicer aeretinum, CanST-2, seems to have an opposite expression pattern, since its transcript level decrease when the growth of epicotyls is inhibited [50]. However, the molecular function of the epicotyl-specific tissue protein in the bud development process remains unknown. A similar protein was found to be down-regulated by low temperatures in peach bark [15].

Three additional genes of unknown function were found up-regulated after several weeks of SD photoperiod. Unknown2 expression was induced by SD photoperiod and cold in other study of SD responses in peach [15]. The unknown 4 sequence showed similarity to a hypothetical protein of Vitis vinifera; however, a putative function and relationship with growth cessation or dormancy could not be assigned. The unknown3 sequence represented a novel transcript in plants. These unknown genes can now be associated with SD responsiveness in peach and may represent novel components of growth cessation and/or dormancy development in peach or other perennial species. Release of the assembled peach genome sequence (ongoing, Dr. Doreen Main, personal communication) will allow the localization of these genes in the genome and determining if they co-localize with genetic and physical map locations known to regulate phenological events such as bud set, chilling requirement, or bud break [51].

\section{Conclusions}

The use of the mutant that fails to undergo growth cessation evg as a biological filter in controlled conditions has allowed us to reduce the number of genes detected by typical differential display experiments during growth cessation and dormancy. The identified genes are putatively involved in growth cessation and/or dormancy entrance and should be downstream of EVG in this pathway. Future proteomic and physiological experiments are required to verify their role in growth cessation and/or dormancy establishment.

\section{Acknowledgements}

The project was supported by the National Research Initiative of the USDA Cooperative State Research, Education and Extension Service grants number 2005-06137 and 2007-35304-17896. We gratefully acknowledge Halina Knap for access to the real-time PCR equipment.

\section{Author details}

'Department of Horticulture, Clemson University, Clemson, SC 29634-0319, USA. ${ }^{2}$ Department of Biological Sciences, Clemson University, Clemson, SC 29634-0314, USA.

\section{Authors' contributions}

SJ and LZ carried out the SSH experiment and drafted the manuscript. S carried out the real-time PCR analyses. GLR assisted in the analysis of the results and drafting of the manuscript. DBG conceived of the study, participated in its design and assisted in the drafting of the manuscript. All the authors read and approved the final manuscript.
Received: 27 August 2009

Accepted: 9 February 2010 Published: 9 February 2010

\section{References}

1. Rohde A, Bhalerao RP: Plant dormancy in the perennial context. Trends in Plant Science 2007, 12(5):217-223.

2. Horvath DP, Anderson JV, Chao WS, Foley ME: Knowing when to grow: signals regulating bud dormancy. Trends in Plant Science 2003, 8(11):534-540.

3. Jackson SD: Plant responses to photoperiod. New Phytologist 2009, 181(3):517-531.

4. Park S, Keathley DE, Han KH: Transcriptional profiles of the annual growth cycle in Populus deltoides. Tree Physiology 2008, 28(3):321-329.

5. Ruttink T, Arend M, Morreel K, Storme V, Rombauts S, Fromm J, Bhalerao RP, Boerjan W, Rohde A: A molecular timetable for apical bud formation and dormancy induction in poplar. Plant Cell 2007, 19(8):2370-2390.

6. Schrader J, Moyle R, Bhalerao R, Hertzberg M, Lundeberg J, Nilsson P, Bhalerao RP: Cambial meristem dormancy in trees involves extensive remodelling of the transcriptome. The Plant Journal 2004, 40(2):173-187.

7. Rohde A, Ruttink T, Hostyn V, Sterck L, Van Driessche K, Boerjan W: Gene expression during the induction, maintenance, and release of dormancy in apical buds of poplar. Journal of Experimental Botany 2007, 58(1516):4047-4060.

8. Yakovlev IA, Fossdal CG, Johnsen O, Junttila O, Skroppa T: Analysis of gene expression during bud burst initiation in Norway spruce via ESTs from subtracted cDNA libraries. Tree Genetics \& Genomes 2006, 2(1):39-52.

9. Derory J, Leger P, Garcia V, Schaeffer J, Hauser MT, Salin F, Luschnig C, Plomion C, Glossl J, Kremer A: Transcriptome analysis of bud burst in sessile oak (Quercus petraea). New Phytologist 2006, 170(4):723-738.

10. Jia $Y$, Anderson JV, Horvath DP, Gu YQ, Lym RG, Chao WS: Subtractive cDNA libraries identify differentially expressed genes in dormant and growing buds of leafy spurge (Euphorbia esula). Plant Molecular Biology 2006, 61(1-2):329-344.

11. Horvath DP, Anderson JV, Soto-Suarez M, Chao WS: Transcriptome analysis of leafy spurge (Euphorbia esula) crown buds during shifts in welldefined phases of dormancy. Weed Science 2006, 54(5):821-827.

12. Horvath DP, Chao WS, Suttle JC, Thimmapuram J, Anderson JV: Transcriptome analysis identifies novel responses and potential regulatory genes involved in seasonal dormancy transitions of leafy spurge (Euphorbia esula L.). BMC Genomics 2008, 9:17.

13. Mazzitelli L, Hancock RD, Haupt S, Walker PG, Pont SDA, McNicol J, Cardle L, Morris J, Viola R, Brennan R, et al: Co-ordinated gene expression during phases of dormancy release in raspberry (Rubus idaeus L.) buds. Journal of Experimental Botany 2007, 58(5):1035-1045.

14. Mathiason K, He D, Grimplet J, Venkateswari J, Galbraith D, Or E, Fennell A: Transcript profiling in Vitis riparia during chilling requirement fulfillment reveals coordination of gene expression patterns with optimized bud break. Functional \& Integrative Genomics 2009, 9(1):81-96.

15. Bassett CL, Wisniewski ME, Artlip TS, Norelli JL, Renaut J, Farrell RE: Global analysis of genes regulated by low temperature and photoperiod in peach bark. Journal of the American Society for Horticultural Science 2006, 131(4):551-563.

16. Yamane $H$, Kashiwa $Y$, Ooka $T$, Tao R, Yonemori K: Suppression subtractive hybridization and differential screening reveals endodormancyassociated expression of an SVP/AGL24 -type MADS-box gene in lateral vegetative buds of japanese apricot. Journal of the American Society for Horticultural Science 2008, 133(5):708-716.

17. Howe GT, Gardner G, Hackett WP, Furnier GR: Phytochrome control of short-day-induced bud set in black cottonwood. Physiologia Plantarum 1996, 97(1):95-103

18. Böhlenius $H$, Huang $T$, Charbonnel-Campaa L, Brunner AM, Jansson $S$, Strauss $\mathrm{SH}$, Nilsson O: CO/FT regulatory module controls timing of flowering and seasonal growth cessation in trees. Science 2006 312(5776):1040-1043.

19. Ruonala R, Rinne PLH, Baghour M, Moritz T, Tuominen H, Kangasjarvi J: Transitions in the functioning of the shoot apical meristem in birch (Betula pendula) involve ethylene. The Plant Journal 2006, 46(4):628-640.

20. Rohde A, Prinsen E, De Rycke R, Engler G, Van Montagu M, Boerjan W: PtABI3 impinges on the growth and differentiation of embryonic leaves during bud set in poplar. Plant Cell 2002, 14(8):1885-1901. 
21. Bielenberg DG, Wang Y, Li ZG, Zhebentyayeva T, Fan SH, Reighard GL, Scorza R, Abbott AG: Sequencing and annotation of the evergrowing locus in peach [Prunus persica (L.) Batsch] reveals a cluster of six MADSbox transcription factors as candidate genes for regulation of terminal bud formation. Tree Genetics \& Genomes 2008, 4(8):495-507.

22. Rodriguez J, Sherman WB, Scorza R, Wisniewski M, Okie WR: 'Evergreen' peach, its inheritance and dormant behavior. Journal of the American Society for Horticultural Science 1994, 119(4):789-792.

23. Bielenberg DG, Wang Y, Fan S, Reighard GL, Scorza R, Abbott AG: A deletion affecting several gene candidates is present in the evergrowing peach mutant. Journal of Heredity 2004, 95(5):436-444.

24. Jiménez S, Lawton-Rauh AL, Reighard GL, Abbott AG, Bielenberg DG: Phylogenetic analysis and molecular evolution of the dormancy associated MADS-box genes from peach. BMC Plant Biology 2009, 9(1):81.

25. Li Z, Reighard GL, Abbott AG, Bielenberg DG: Dormancy-associated MADS genes from the EVG locus of peach [Prunus persica (L.) Batsch] have distinct seasonal and photoperiodic expression patterns. Journal of Experimental Botany 2009, 60(12):3521-3530.

26. Wang Y, Georgi LL, Reighard GL, Scorza R, Abbott AG: Genetic mapping of the evergrowing gene in peach Prunus persica (L.) Batsch. Journal of Heredity 2002, 93(5):352-358.

27. Meisel L, Fonseca B, Gonzalez S, Baeza-Yates R, Cambiazo V, Campos R, Gonzalez M, Orellana A, Retamales J, Silva H: A rapid and efficient method for purifying high quality total RNA from peaches (Prunus persica) for functional genomics analyses. Biological Research 2005, 38(1):83-88.

28. Ruijter JM, Ramakers C, Hoogaars WMH, Karlen Y, Bakker O, Hoff van den MJB, Moorman AFM: Amplification efficiency: linking baseline and bias in the analysis of quantitative PCR data. Nucleic Acids Research 2009, 37(6): e45.

29. Schefe JH, Lehmann KE, Buschmann IR, Unger T, Funke-Kaiser $\mathrm{H}$ : Quantitative real-time RT-PCR data analysis: current concepts and the novel "gene expression's $C_{T}$ difference" formula. Journal of Molecular Medicine 2006, 84(11):901-910.

30. Czechowski T, Stitt M, Altmann T, Udvardi MK, Scheible WR: Genome-wide identification and testing of superior reference genes for transcript normalization in Arabidopsis. Plant Physiology 2005, 139(1):5-17.

31. Brunner AM, Yakovlev IA, Strauss SH: Validating internal controls for quantitative plant gene expression studies. BMC Plant Biology 2004, 4(14).

32. Arora $R$, Rowland $L$, Tanino $K$ : Induction and release of bud dormancy in woody perennials: A science comes of age. Hortscience 2003, 38(5):911-921

33. Ohmiya A, Tanaka $Y$, Kadowaki $K$, Hayashi T: Cloning of genes encoding auxin-binding proteins (ABP19/20) from peach: Significant peptide sequence similarity with germin-like proteins. Plant and Cell Physiology 1998, 39(5):492-499

34. Venis MA, Napier RM, Barbierbrygoo H, Maurel C, Perrotrechenmann C, Guern J: Antibodies to a peptide from the maize auxin-binding protein have auxin agonist activity. Proceedings of the National Academy of Sciences of the United States of America 1992, 89(15):7208-7212.

35. Ohmiya A: Characterization of ABP19/20, sequence homologues of germin-like protein in Prunus persica L. Plant Science 2002, 163(4):683-689.

36. Chen JG, Ullah H, Young JC, Sussman MR, Jones AM: ABP1 is required for organized cell elongation and division in Arabidopsis embryogenesis. Genes \& Development 2001, 15(7):902-911.

37. David KM, Couch D, Braun N, Brown S, Grosclaude J, Perrot-Rechenmann C: The auxin-binding protein 1 is essential for the control of cell cycle. The Plant Journal 2007, 50(2):197-206

38. Chen JG, Wang SC, Lazarus CM, Napier RM, Jones AM: Altered expression of auxin-binding protein 1 affects cell expansion and auxin pool size in tobacco cells. Journal of Plant Growth Regulation 2006, 25(1):69-78.

39. Timpte C: Auxin binding protein: curiouser and curiouser. Trends in Plant Science 2001, 6(12):586-590.

40. Renaut J, Hausman JF, Bassett C, Artlip T, Cauchie HM, Witters E, Wisniewski M: Quantitative proteomic analysis of short photoperiod and low-temperature responses in bark tissues of peach (Prunus persica $\mathrm{L}$. Batsch). Tree Genetics \& Genomes 2008, 4(4):589-600.

41. Uggla C, Moritz T, Sandberg G, Sundberg B: Auxin as a positional signal in pattern formation in plants. Proceedings of the National Academy of Sciences of the United States of America 1996, 93(17):9282-9286.
42. Eliasson A, Gass N, Mundel C, Baltz R, Krauter R, Evrard IL, Steinmetz A: Molecular and expression analysis of a LIM protein gene family from flowering plants. Molecular \& General Genetics 2000, 264(3):257-267.

43. Stone SL, Williams LA, Farmer LM, Vierstra RD, Callis J: KEEP ON GOING, a RING E3 ligase essential for Arabidopsis growth and development, is involved in abscisic acid signaling. Plant Cell 2006, 18(12):3415-3428.

44. Durand A, Hughes R, Roussel A, Flatman R, Henrissat B, Juge N: Emergence of a subfamily of xylanase inhibitors within glycoside hydrolase family 18. The FEBS Journal 2005, 272(7):1745-1755.

45. Geisler-Lee J, Geisler M, Coutinho PM, Segerman B, Nishikubo N, Takahashi J, Aspeborg H, Djerbi S, Master E, Andersson-Gunneras S, et al: Poplar carbohydrate-active enzymes. Gene identification and expression analyses. Plant Physiology 2006, 140(3):946-962.

46. Hundertmark M, Hincha DK: LEA (Late Embryogenesis Abundant) proteins and their encoding genes in Arabidopsis thaliana. BMC Genomics 2008, 9.

47. Artlip TS, Callahan AM, Bassett CL, Wisniewski ME: Seasonal expression of a dehydrin gene in sibling deciduous and evergreen genotypes of peach (Prunus persica [L.] Batsch). Plant Molecular Biology 1997, 33(1):61-70.

48. Rothan C, Etienne C, Moing A, Dirlewanger E, Raymond P, Monet R: Isolation of a CDNA encoding a metallothionein-like protein (accession No. AJ243532) expressed during peach fruit development. (PGR99-126) Plant Physiology 1999, 121:311.

49. Riviere MP, Marais A, Ponchet M, Willats W, Galiana E: Silencing of acidic pathogenesis-related $P R-1$ genes increases extracellular beta-(1 -> 3)glucanase activity at the onset of tobacco defence reactions. Journal of Experimental Botany 2008, 59(6):1225-1239.

50. Muñoz FJ, Dopico B, Labrador E: Two growth-related organ-specific cDNAs from Cicer arietinum epicotyls. Plant Molecular Biology 1997, 35(4):433-442.

51. Fan S, Bielenberg DG, Zhebentyayeva T, Reighard GL, Abbott A: Mapping quantitative trait loci associated with chilling requirement, heat requirement and blooming date in peach. Plant \& Animal Genomes XVII Conference: January 10-14 2009; San Diego, CA; 2009, 435.

doi:10.1186/1471-2229-10-25

Cite this article as: Jiménez et al: Identification of genes associated with growth cessation and bud dormancy entrance using a dormancyincapable tree mutant. BMC Plant Biology 2010 10:25.

\section{Submit your next manuscript to BioMed Central and take full advantage of:}

- Convenient online submission

- Thorough peer review

- No space constraints or color figure charges

- Immediate publication on acceptance

- Inclusion in PubMed, CAS, Scopus and Google Scholar

- Research which is freely available for redistribution

Submit your manuscript at www.biomedcentral.com/submit
C Biomed Central 